Check for updates

Cite this: RSC Adv., 2021, 11, 25179

Received 14th April 2021

Accepted 14th July 2021

DOI: 10.1039/d1ra02914b

rsc.li/rsc-advances

\section{A high throughput computational investigation of the solid solution mechanisms of actinides and lanthanides in zirconolite $\uparrow$}

\author{
Stavrina Dimosthenous, (D) a Christopher M. Handley, (DD ab Lewis R. Blackburn, ${ }^{a}$ \\ Colin L. Freeman ${ }^{a}$ and Neil C. Hyatt (D)*a
}

\begin{abstract}
In this work, we perform a theoretical investigation of the actinide and lanthanide solid solution mechanisms of zirconolite-2M, prototypically $\mathrm{CaZrTi}_{2} \mathrm{O}_{7}$, as a candidate immobilisation matrix for plutonium. Solid solution energies were calculated using static atomistic simulations by means of the General Utility Lattice Program, for formulations of relevance to ceramic wasteform deployment, with substitution on the $\mathrm{Ca}^{2+}$ and $\mathrm{Zr}^{4+}$ sites by $\mathrm{Ce}^{4+}, \mathrm{Pu}^{4+}, \mathrm{Th}^{4+}$, and $\mathrm{U}^{4+}$, and appropriate charge balance by substitution of $\mathrm{Al}^{3+}$ or $\mathrm{Fe}^{3+}$ on $\mathrm{Ti}^{4+}$ sites. In simple solid solutions involving substitution on the $\mathrm{Zr}^{4+}$ site, we found that whereas substitution of $\mathrm{Ce}^{4+}, \mathrm{U}^{4+}$ and $\mathrm{Pu}^{4+}$ were energetically favoured, substitution of $\mathrm{Th}^{4+}$ was not energetically favoured. For more complex solid solutions involving $\mathrm{Ce}^{4+}, \mathrm{Pu}^{4+}, \mathrm{Th}^{4+}$, and $\mathrm{U}^{4+}$ substitution on the $\mathrm{Ca}^{2+}$ site, we found the most energetically favoured scheme involved co-substitution of $\mathrm{Al}^{3+}$ or $\mathrm{Fe}^{3+}$ on the five-fold co-ordinate $\mathrm{Ti}^{4+}$ site in the zirconolite-2M structure. Comparison of these computational data with experimental evidence, where available, demonstrated broad agreement. Consequently, this study provides useful insight into formulation design and the efficacy of $\mathrm{Ce}^{4+}, \mathrm{U}^{4+}$ and $\mathrm{Th}^{4+}$ as $\mathrm{Pu}^{4+}$ surrogates in zirconolite-2M ceramic wasteforms for plutonium disposition.
\end{abstract}

\section{Introduction}

The UK holds the world's largest inventory of separated civil plutonium, forecast to reach 140 tons at the end of reprocessing operations. ${ }^{1}$ UK government policy is to manage this material to a safe and secure end point, the preferred strategy for which is reuse in mixed oxide (MOX) fuel in light water reactors. However, should this strategy not prove implementable, immobilisation of the inventory will be required, along with the fraction of material known to be unsuitable for MOX fuel manufacture.

Numerous natural and synthetic materials have been proposed as wasteforms for the immobilisation of actinides, these including ceramics, glasses, and glass-ceramics. ${ }^{2-6}$ Geological disposal of actinides places greater emphasis on the performance of the wasteform and near field barriers, so as to assure adequate containment of fissile material over the required timescales, which, in the geological context, are comparably short. ${ }^{2-5,7}$ Zirconolite, prototypically $\mathrm{CaZrTi}_{2} \mathrm{O}_{7}$, is a naturally occurring mineral and the dominant actinide

${ }^{a}$ Department of Materials Science and Engineering, The University of Sheffield, Mappin Street, Sheffield, UK. E-mail: stavrinadimosthenous@gmail.com; n.c.hyatt@sheffield. ac.uk

${ }^{b}$ The Digital Research Service, The School of Computing, Jubilee Campus, The University of Nottingham, Nottingham, UK

$\dagger$ Electronic supplementary information (ESI) available. See DOI: $10.1039 / \mathrm{d} 1 \mathrm{ra} 02914 \mathrm{~b}$ bearing phase in the SYNROC C ceramic wasteform;, ${ }^{8,9}$ it is known to be highly resistant to alteration and dissolution. ${ }^{10,11}$ As a result, zirconolite is an attractive material for plutonium immobilisation and its potential as a wasteform has been well established. ${ }^{\mathbf{8}, 12-15}$ The zirconolite-2M polytype structure (space group $C 2 / c$ ), adopted by the prototypical composition $\mathrm{CaZrTi}_{2}-$ $\mathrm{O}_{7}$, comprises alternating layers of $\mathrm{CaO}_{8}$ and $\mathrm{ZrO}_{7}$ polyhedra aligned parallel to (110); parallel to the [001] direction, these polyhedra are interleaved $1: 1$ with hexagonal tungsten bronze motifs formed by corner sharing $\mathrm{TiO}_{6}$ and $\mathrm{TiO}_{5}$ polyhedra. ${ }^{16,17}$ The $2 \mathrm{M}$ nomenclature thus signifies a monoclinic unit cell with a two layer repeat sequence along [001]; other zirconolite polytype structures with different interlayer relationships are known, as discussed below.

The use of $\mathrm{Pu}$ in laboratory based studies is hazardous, challenging and expensive. Consequently, $\mathrm{Ce}, \mathrm{U}$ and $\mathrm{Th}$ are frequently used as inactive or low active surrogates to emulate the behaviour of Pu in laboratory based studies. ${ }^{18,19}$ This is due to the similarity of the ionic size of $\mathrm{Ce}^{4+}, \mathrm{U}^{4+}, \mathrm{Th}^{4+}$ and $\mathrm{Pu}^{4+}$ and to $\mathrm{CeO}_{2}, \mathrm{PuO}_{2}, \mathrm{ThO}_{2}$, and $\mathrm{UO}_{2}$ all having a common fluorite crystal structure and exhibiting solid solution at any ratio, implying similar solid state chemistry. ${ }^{20-23}$

In this work we aim to investigate the plutonium immobilisation potential of zirconolite-2M by atomistic simulations. Previous simulation based studies of zirconolite-2M at the atomistic level have focused on studying the defect chemistry of actinide additions, ${ }^{24}$ and within the regime of molecular 
dynamics for investigations the radiation damaged structure, and crystalline to amorphous phase transition, arising from $\alpha$ decay of $\mathrm{Pu} .^{25-27}$ More recently, Ce and actinide solid solution mechanisms in zirconolite-2M were studied at the electronic structure level, within the density functional theory (DFT) regime. ${ }^{28}$ Importantly, the DFT investigation of Tanti et al. broadly agreed with findings of the atomistic simulations of Gilbert et al. for Ce-substituted zirconolite-2M. The choice of methodology and accuracy level is a critical consideration in such investigations. The broad agreement between DFT and atomistic simulations shows that we can obtain accurate insight with the atomistic approach. Further, given the low computational cost, it is feasible to simulate relatively large lattices at the atomistic level employing an innovative high-throughput workflow described herein.

Our investigation develops and extends a previous computational study of the defect chemistry of zirconolite-2M, ${ }^{24}$ with regard to incorporation of $\mathrm{Ce}^{3+/ 4+}$ and $\mathrm{Pu}^{3+/ 4+}$. In this contribution we expand the previous study by examining the solid solution of $\mathrm{Pu}^{4+}$ and its typical surrogates, $\mathrm{Ce}^{4+}, \mathrm{U}^{4+}, \mathrm{Th}^{4+}$, on the $\mathrm{Ca}^{2+}$ and $\mathrm{Zr}^{4+}$ sites, at concentrations greater than point defects, with necessary charge compensation provided by $\mathrm{Al}^{3+}$ and $\mathrm{Fe}^{3+}$ substitution on the $\mathrm{Ti}^{4+}$ sites.

We focus on the $\mathrm{Pu}^{4+}$ oxidation state which has been shown to be the dominant species in fluorite related zirconolite-2M and pyrochlore structured ceramics synthesised under conditions relevant to wasteform manufacture. ${ }^{29-33}$ Under conditions of hot isostatic pressing with $\mathrm{PuO}_{2}$ as a feedstock, synthesis of the zirconolite ceramic wasteform will be under the redox control of the Fe/FeO buffer imposed by the stainless steel can. Consideration of Ellingham diagrams shows that this will not be sufficient to effect $\mathrm{PuO}_{2} / \mathrm{Pu}_{2} \mathrm{O}_{3}$ reduction. ${ }^{34}$ Indeed, $\mathrm{Pu}^{3+}$ is stabilised by annealing only under strongly reducing $5 \% \mathrm{H}_{2} / \mathrm{N}_{2}$, or $5 \% \mathrm{H}_{2} / \mathrm{Ar}$, which is not relevant to the technological focus of wasteform manufacture by hot isostatic pressing. ${ }^{31,32}$

\section{Theory}

The work presented in this paper examines three substitution schemes to investigate $\mathrm{Pu}$ and surrogate incorporation in zirconolite-2M. The substitution schemes are based on compositions relevant to optimisation of zirconolite ceramic formulations. We used the supercell approach to study the defects of the system. Here, the defects are added as absolute concentrations in a solid solution, and our concentration values can therefore be directly compared to experimental compositions. This differs from previous work on this system ${ }^{24}$ that used a Mott-Littleton method where the substitution defects were effectively at infinite dilution.

In the first substitution scheme, we replaced $\mathrm{Zr}^{4+}$ sites in prototypical zirconolite-2M with $\mathrm{Ce}^{4+}, \mathrm{Pu}^{4+}, \mathrm{Th}^{4+}$ and $\mathrm{U}^{4+}$. The chemical reaction for the substitution scheme was as follows,

$$
\mathrm{CaZrTi}_{2} \mathrm{O}_{7}+x \mathrm{MO}_{2} \rightarrow \mathrm{CaZr}_{1-x} \mathrm{M}_{x} \mathrm{Ti}_{2} \mathrm{O}_{7}+x \mathrm{ZrO}_{2}
$$

where $\mathrm{M}=\mathrm{Ce}, \mathrm{Pu}, \mathrm{Th}, \mathrm{U}$. Here, $2 \mathrm{M}$ denotes the polytype structure of monoclinic symmetry.
The second substitution scheme targeted the substitution of $\mathrm{Ce}^{4+}, \mathrm{Pu}^{4+}, \mathrm{Th}^{4+}$ and $\mathrm{U}^{4+}$ on the $\mathrm{Ca}^{2+}$ site, with charge balance provided by replacing $2 \mathrm{Ti}^{4+}$ sites with $\mathrm{Al}^{3+}$, for every $\mathrm{Ca}^{2+}$ ion replaced. ${ }^{35-37}$ The second substitution scheme followed the reaction,

$$
\begin{gathered}
\mathrm{CaZrTi}_{2} \mathrm{O}_{7}+x \mathrm{MO}_{2}+x \mathrm{Al}_{2} \mathrm{O}_{3} \rightarrow \mathrm{Ca}_{1-x} \mathrm{M}_{x} \mathrm{ZrTi}_{2-2 x} \mathrm{Al}_{2 x} \mathrm{O}_{7}+ \\
x \mathrm{CaO}+2 x \mathrm{TiO}_{2}
\end{gathered}
$$

where $\mathrm{M}=\mathrm{Ce}, \mathrm{Pu}$, Th, $\mathrm{U}$.

There are three unique $\mathrm{Ti}^{4+}$ sites in the zirconolite-2M structure that may accommodate charge balancing cations such as $\mathrm{Al}^{3+}$. An illustration of the $\mathrm{Ti}^{4+}$ site orientations and coordination is shown in Fig. 1, where example $\mathrm{Ti}(1), \mathrm{Ti}(2)$ and $\mathrm{Ti}(3)$ sites are coloured in green, yellow and fuschia respectively, with $\mathrm{Ca}$ and $\mathrm{Zr}$ omitted for clarity. The $\mathrm{Ti}(1)$ and $\mathrm{Ti}(3)$ sites adopt octahedral co-ordination by $\mathrm{O}^{2-}$, whereas the $\mathrm{Ti}(2)$ site adopts a trigonal bipyramidal configuration by $\mathrm{O}^{2-}$. The $\mathrm{Ti}(2)$ site is partially occupied, with a $50 \%$ probability of lying either side of the site axis. ${ }^{\mathbf{1 6}}$

Experimental studies have shown that charge balancing ions are generally preferentially accommodated in the 5-fold coordinate $\operatorname{Ti}(2)$ site. $^{36-38}$ Although, in some instances, charge balancing species such as $\mathrm{Cr}^{3+}$ have been shown to preferentially adopt 6 -fold $\mathrm{Ti}^{4+}$ sites as may be expected from consideration of crystal field stabilisation energy. ${ }^{34}$ Therefore, this substitution scheme needs to consider potential preferential substitution of the charge balancing ions for particular $\mathrm{Ti}^{4+}$ sites. To address this question, we considered 6 different $\mathrm{Al}^{3+}$ site combinations: two $\mathrm{Ti}(1)$ sites; two $\mathrm{Ti}(2)$ sites; two $\mathrm{Ti}(3)$ sites; one $\operatorname{Ti}(1)$ and one $\operatorname{Ti}(2)$; one $\operatorname{Ti}(1)$ and one $\operatorname{Ti}(3)$; and one $\operatorname{Ti}(2)$ and one $\operatorname{Ti}(3)$.

The third substitution scheme was identical to the second scheme, however, the reaction was charge balanced with $\mathrm{Fe}^{3+} \cdot{ }^{39}$ The third substitution scheme followed the reaction,

$$
\begin{gathered}
\mathrm{CaZrTi}_{2} \mathrm{O}_{7}+x \mathrm{MO}_{2}+x \mathrm{Fe}_{2} \mathrm{O}_{3} \rightarrow \mathrm{Ca}_{1-x} \mathrm{M}_{x} \mathrm{ZrTi}_{2-2 x} \mathrm{Fe}_{2 x} \mathrm{O}_{7}+ \\
x \mathrm{CaO}+2 x \mathrm{TiO}_{2}
\end{gathered}
$$

where $\mathbf{M}=\mathrm{Ce}, \mathrm{Pu}, \mathrm{Th}, \mathrm{U}$.

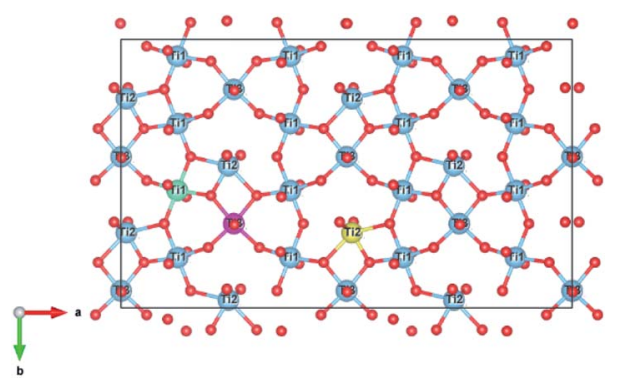

Fig. $1 \mathrm{Ti}^{4+}$ site orientation in our base zirconolite-2M system $\left(\mathrm{Ca}^{2+}\right.$, $\mathrm{Zr}^{4+}$ hidden). Ti sites are labelled, example Ti(1), Ti(2) and Ti(3) sites are coloured green, yellow and fuchsia, respectively. The Ti(1) and Ti(3) sites have octahedral coordination, whereas the Ti(2) site has trigonal bipyramidal co-ordination and is $50 \%$ occupied. Figure generated in VESTA. ${ }^{40}$ 


\section{Method}

All the calculations in this work were performed with the General Utility Lattice Program (GULP). ${ }^{41}$ Ions are treated as charged spheres represented by their formal charge ${ }^{\mathbf{4 2}}$ with a coulombic attraction/repulsion. Short range interactions between ions are described with Buckingham potentials of the form,

$$
E_{\mathrm{ij}}=A \exp \left(\frac{r_{\mathrm{ij}}}{\rho}\right)-\frac{C_{6}}{r_{\mathrm{ij}}{ }^{6}}
$$

where $r_{\mathrm{ij}}$ is the distance between two ions i and $\mathrm{j}$, and $A, \rho$ and $C_{6}$ are parametrised constants specific to each interaction pair, as summarised in Table 1.

The polarisability of the system is described by the shell model $^{43}$ where the charged core interacts with a massless "shell" via a spring constant, $k$. Only $\mathrm{O}^{2-}$ was polarised in this study so the interaction potentials presented in Table 1 are cation-anion core-shell interaction potentials. The shell model data for $\mathrm{O}^{2-}$ are presented in Table 2.

The model zirconolite lattice is the stoichiometric $2 \mathrm{M}$ polytype taken from the work of Gilbert et al. ${ }^{24}$ based on the structure published by Rossell. ${ }^{17}$ For our simulations the structure was expanded to a $2 \times 2 \times 2$ supercell (704 atoms). The calculations were performed at constant pressure and the structure and atomic positions were optimised using a Broyden-Fletcher-Goldfarb-Shanno (BFGS) algorithm. ${ }^{44-47}$

Substitution sites were randomly chosen. Our base zirconolite-2M system was composed of 704 atoms, 64 of those were $\mathrm{Zr}^{4+}, 64$ were $\mathrm{Ca}^{2+}, 128$ were $\mathrm{Ti}^{4+}$ (64 $\mathrm{Ti}(1), 32 \mathrm{Ti}(2), 32$ Ti(3)). For the first solid solution scheme, we chose to produce 30 random site substitution configurations. For the second solid solution scheme we produced 120 random configurations per site combination, e.g. $\operatorname{CeTi}(1) \operatorname{Ti}(1)$. That is, for every substitution introduced to the system we replaced one $\mathrm{Ca}^{2+}$ site at random and two of the chosen type of $\mathrm{Ti}^{4+}$ sites at random with $\mathrm{Al}^{3+}$. For the third solid solution scheme, our aim was to directly compare $\mathrm{Al}^{3+}$ and $\mathrm{Fe}^{3+}$ as charge balancing species. Therefore, we made a direct substitution of $\mathrm{Fe}^{3+}$ on the sites that were occupied by $\mathrm{Al}^{3+}$ in the second solid solution scheme. The structures remained identical, otherwise. In our simulations we

Table 1 Force field parameters for Buckingham potentials used in this work

\begin{tabular}{lcccc}
\hline Interaction & \multicolumn{1}{c}{$A(\mathrm{eV})$} & $\rho(\AA)$ & $C_{6}\left(\mathrm{eV} \AA^{6}\right)$ & Ref. \\
\hline $\mathrm{O}^{2-}-\mathrm{O}^{2-}$ & 25.410 & 0.6937 & 32.320 & 48 \\
$\mathrm{Ca}^{2+}-\mathrm{O}^{2-}$ & 2272.741 & 0.2986 & 0.000 & 48 \\
$\mathrm{Zr}^{4+}-\mathrm{O}^{2-}$ & 7290.347 & 0.2610 & 0.000 & 49 \\
$\mathrm{Ti}^{4+}-\mathrm{O}^{2-}$ & 4545.823 & 0.2610 & 0.000 & 49 \\
$\mathrm{Al}^{3+}-\mathrm{O}^{2-}$ & 2409.505 & 0.2649 & 0.000 & 48 \\
$\mathrm{Fe}^{3+}-\mathrm{O}^{2-}$ & 3219.335 & 0.2641 & 0.000 & 48 \\
$\mathrm{Ce}^{4+}-\mathrm{O}^{2-}$ & 2409.505 & 0.3260 & 0.000 & 49 \\
$\mathrm{Pu}^{4+}-\mathrm{O}^{2-}$ & 752.224 & 0.4007 & 0.000 & 24 \\
$\mathrm{Th}^{4+}-\mathrm{O}^{2-}$ & 8638.5 & 0.2856 & 70.000 & 50 \\
$\mathrm{U}^{4+}-\mathrm{O}^{2-}$ & 9296.65 & 0.2796 & 90.000 & 50
\end{tabular}

Table 2 Shell parameters for $\mathrm{O}^{2-}$ used in this work

\begin{tabular}{lll}
\hline $\begin{array}{l}\text { Effective charge } \\
\text { (core/shell) }\end{array}$ & $k\left(\mathrm{eV} \mathrm{\AA}^{-2}\right)$ & Ref. \\
\hline $0.513 /-2.513$ & 20.53 & 51
\end{tabular}

considered substitution concentrations of 3, 6, 9, 12, 15, 18 and $21 \%$. In practice, this was the percentage of the number of atoms of the element in the cell to be replaced by the substitution rounded to the nearest integer, which was 2, 4, 6, 8, 10, 12 and 13 sites for $\mathrm{Zr}^{4+}$ and $\mathrm{Ca}^{2+}$, and 4, 8, 12, 20, 24 and 26 sites for $\mathrm{Ti}^{4+}$, when considering $\mathrm{Al}^{3+}$ and $\mathrm{Fe}^{3+}$ charge compensation. For a cell of 704 atoms, there were $64 \mathrm{Zr}^{4+}$ and $64 \mathrm{Ca}^{2+}$ sites that were potential substitution sites. Therefore, we were able to sample a wide range of configurations without artificial symmetry restrictions and provide data that could be compared to experimental investigation. Importantly, the upper substitution limit in this study concentration approximates that required for wasteform deployment.

Once the groundstate energy for each randomly substituted lattice was obtained we calculated the solution energy, that is the enthalpy of solid solution, for each substitution scheme. The calculation was based on the reactions presented in Section 2. We obtained the energy of each component by performing a geometry optimisation calculation on each structure, we assumed the polymorph of $\mathrm{TiO}_{2}$ to be rutile.

Configurations that failed to optimise were removed from the spread of data. The solution energies were averaged. For an optimised spread the ground state energy differed by $2 \mathrm{eV}$ to $3 \mathrm{eV}$. Each point on the graphs presented in Fig. 3 is the average solution energy for the denoted $\mathrm{M}^{4+}$ concentration. Each line presented in Fig. 4 and 5 is the trend in the average solution energy over all substitutions for each scheme. Where the trend in the solution energy of a substitution did not follow the global trend in the scheme, it is presented separately on the same graph with a dashed line.

To perform the above randomisation of site substitution in structures for each solid solution scheme, we wrote Python based software to enable the automation of the generation of the structures that are then passed to a high-performance computer server, enabling us to rapidly perform simulations and, from the following analysis, provide meaningful suggestions for material synthesis. An example time frame would be about 1-12 hours per simulation on a single core, with simulations queued as an array job; this resulted in about 2 days for the 120 simulation cell analyses from queueing to data clean-up and analysis. The above workflow is illustrated in Fig. 2.

Importantly, Fig. 2 extends the work performed in this study to a pipeline workflow for high-throughput materials discovery. Enclosed within the box is the work performed within this paper. Outside of the box are future steps that can be performed where more expensive computational methods are applied. This demonstrates the method of use computationally cheaper methods - force fields - to scan the search space of crystal structure to quickly provide targets for investigation by more expensive methods. Within the context of the work here, this is 


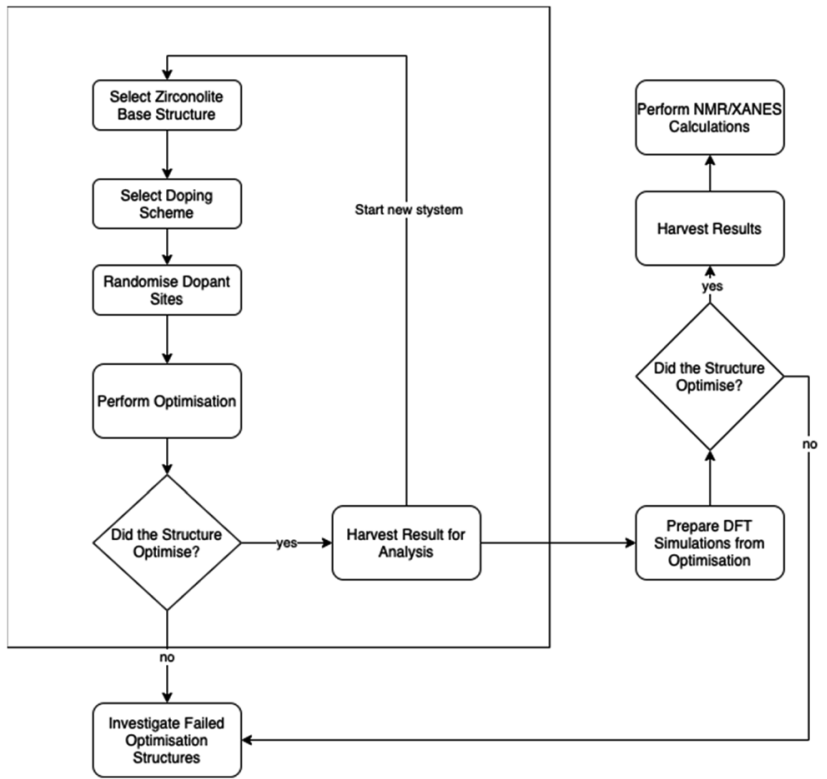

Fig. 2 Flowchart demonstrating the high throughput methodology described in the Method section.

beneficial when it is impractical to physically synthesise all possible solid solution stoichiometries. Within the wider context of materials science, our method has application to the exploration of similar materials e.g. high entropy alloys, capacitor ceramics, perovskites. Furthermore, the use of this initial screening can then direct subsequent, more costly, $a b$ initio simulations, where the initial screening method has narrowed down the range of target compositions. The full calculation outputs are presented in the associated ESI. $\dagger$

\section{Results}

\section{1 $\mathrm{CaZr}_{1-x} \mathrm{M}_{x} \mathrm{Ti}_{2} \mathrm{O}_{7}(\mathrm{M}=\mathrm{Ce}, \mathrm{Pu}, \mathrm{Th}, \mathrm{U})$}

Fig. 3 shows the mean solution energy for the following scheme, plotted against $\mathrm{Ce}, \mathrm{Pu}, \mathrm{Th}$, and $\mathrm{U}$ concentration.

$$
\mathrm{CaZrTi}_{2} \mathrm{O}_{7}+x \mathrm{MO}_{2} \rightarrow \mathrm{CaZr}_{1-x} \mathrm{M}_{x} \mathrm{Ti}_{2} \mathrm{O}_{7}+x \mathrm{ZrO}_{2}
$$

The solution energies of $\mathrm{Ce}^{4+}$ and $\mathrm{Pu}^{4+}$ substitution on the $\mathrm{Zr}^{4+}$ site become progressively more negative with increasing

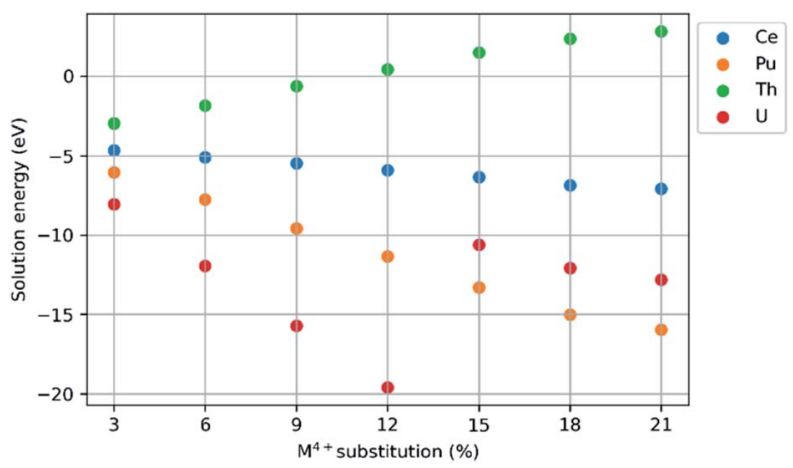

Fig. 3 Comparison of solution energy as a function of $\mathrm{M}^{4+}$ substitution on the $\mathrm{Zr}^{4+}$ site $(\mathrm{M}=\mathrm{Ce}, \mathrm{Pu}, \mathrm{Th}, \mathrm{U})$.
$\mathrm{Ce}^{4+}$ and $\mathrm{Pu}^{4+}$ concentration; the slope for $\mathrm{Pu}^{4+}$ is greater than for $\mathrm{Ce}^{4+}$. In contrast, for $\mathrm{Th}^{4+}$ substitution, an increase in solution energy is observed with increasing concentration. The solution energy for $\mathrm{U}^{4+}$ substitution initially follows a downward trend, however, beyond a $\mathrm{U}$ concentration of $12 \%$, there is an abrupt increase in solution energy. Thereafter, the solution energies for $\mathrm{U}^{4+}$ substitution follow a downward trend despite the discontinuity in solution energy from $12-15 \%$ concentration.

\section{2 $\mathrm{Ca}_{1-x} \mathrm{M}_{x} \mathrm{ZrTi}_{2-2 x} \mathrm{Al}_{2 x} \mathrm{O}_{7}(\mathrm{M}=\mathrm{Ce}, \mathrm{Pu}, \mathrm{Th}, \mathrm{U})$}

Results for $\mathrm{Ce}^{4+}, \mathrm{Pu}^{4+}, \mathrm{Th}^{4+}$ and $\mathrm{U}^{4+}$ substitution on the $\mathrm{Ca}^{2+}$ site and charge balance by replacement of $\mathrm{Ti}^{4+}$ with $\mathrm{Al}^{3+}$, are presented in Fig. 4. The mean solution energies are plotted against $\mathrm{M}^{4+}$ substitution concentration, with $\mathrm{Al}^{3+}$ as the charge balancing species substituted on sites $\operatorname{Ti}(1) \operatorname{Ti}(1), \operatorname{Ti}(2) \operatorname{Ti}(2), \operatorname{Ti}(3)$ $\operatorname{Ti}(3), \operatorname{Ti}(1) \operatorname{Ti}(2)$, Ti(1)Ti(3), and $\operatorname{Ti}(2) \operatorname{Ti}(3)$. The solution energies of particular substitution schemes which do not follow the general trends are plotted separately with their own dashed lines. There is an upward trend in solution energy with increasing $\mathrm{Ce}, \mathrm{Pu}$, Th and $\mathrm{U}$ concentration for all schemes involving substitution on either the $\operatorname{Ti}(1)$ or $\operatorname{Ti}(3)$ sites, and the solution energy is always positive above an $\mathrm{M}^{4+}$ concentration of $6 \%$. The solution energy only decreases with increasing $\mathrm{M}^{4+}$ concentration when charge balancing with $\mathrm{Al}^{3+}$ on the Ti(2)Ti(2) site combination, for which the solution energy is always negative.

While $\mathrm{Pu}^{4+}$ substitution with $\mathrm{Al}^{3+}$ charge balance on two Ti(1) sites follows the general trend of the other substitutions, where the solution energy increases with increasing concentration, we observe maxima in the solution energy at $6 \%, 12 \%$ and $21 \% \mathrm{M}^{4+}$ concentration. In the case of $\mathrm{Al}^{3+}$ charge balance on the combination of $\mathrm{Ti}(1)$ and $\mathrm{Ti}(3)$ sites, $\mathrm{Ce}^{4+}$ substitution did not follow the trend of $\mathrm{Pu}^{4+}, \mathrm{Th}^{4+}$ and $\mathrm{U}^{4+}$ so the data for it is plotted individually on the graph.

\section{3 $\mathrm{Ca}_{1-x} \mathrm{M}_{x} \mathrm{ZrTi}_{2-2 x} \mathrm{Fe}_{2 x} \mathrm{O}_{7}(\mathrm{M}=\mathrm{Ce}, \mathrm{Pu}, \mathrm{Th}, \mathrm{U})$}

Fig. 5 shows the results for substitution of $\mathrm{Ce}^{4+}, \mathrm{Pu}^{4+}, \mathrm{Th}^{4+}$ and $\mathrm{U}^{4+}$ substitution on the $\mathrm{Ca}^{2+}$ site of the zirconolite-2M structure with charge balance by replacement of $\mathrm{Ti}^{4+}$ with $\mathrm{Fe}^{3+}$. The mean

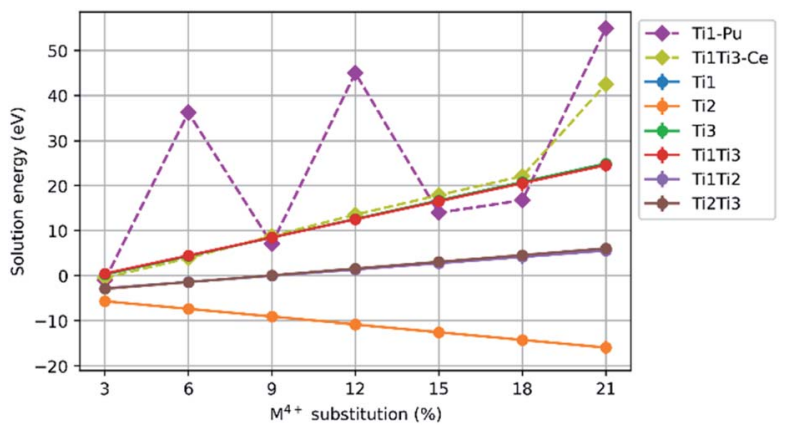

Fig. 4 Comparison of solution energy as a function of $\mathrm{M}^{4+}$ substitution on the $\mathrm{Ca}^{2+}$ site with charge balance of $\mathrm{Al}^{3+}$ on $\mathrm{Ti}^{4+}$ site combinations, $\mathrm{Ti}(1) \mathrm{Ti}(1), \mathrm{Ti}(2) \mathrm{Ti}(2), \mathrm{Ti}(3) \mathrm{Ti}(3), \mathrm{Ti}(1) \mathrm{Ti}(2), \mathrm{Ti}(1) \mathrm{Ti}(3)$, and $\mathrm{Ti}(2) \mathrm{Ti}(3)$ sites $(M=\mathrm{Ce}, \mathrm{Pu}, \mathrm{Th}, \mathrm{U})$. 


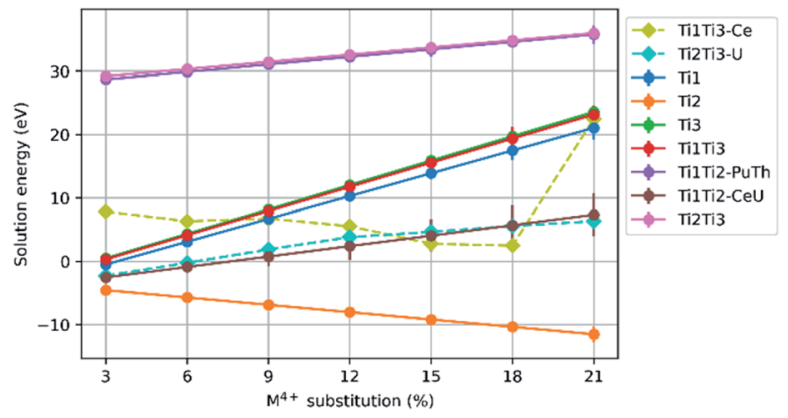

Fig. 5 Comparison of solution energy as a function of $\mathrm{M}^{4+}$ substitution on the $\mathrm{Ca}^{2+}$ site and charge balance of $\mathrm{Fe}^{3+}$ on $\mathrm{Ti}^{4+}$ site combinations, $\mathrm{Ti}(1) \mathrm{Ti}(1), \mathrm{Ti}(2) \mathrm{Ti}(2), \mathrm{Ti}(3) \mathrm{Ti}(3), \mathrm{Ti}(1) \mathrm{Ti}(2), \mathrm{Ti}(1) \mathrm{Ti}(3)$, and $\mathrm{Ti}(2) \mathrm{Ti}(3)$ sites $(M=C e, P u, T h, U)$.

solution energies are plotted against $\mathrm{M}^{4+}$ substitution concentration, with $\mathrm{Fe}^{3+}$ as the charge balancing species substituted on sites $\operatorname{Ti}(1) \operatorname{Ti}(1)$, Ti(2)Ti(2), Ti(3)Ti(3), Ti(1)Ti(2), Ti(1)Ti(3), and $\operatorname{Ti}(2) \operatorname{Ti}(3)$. Again, the solution energies of particular substitution schemes which do not follow the general trends are plotted separately with their own dashed lines.

The general trends in solution energy with $\mathrm{Fe}^{3+}$ as a charge balancing species are similar to those of $\mathrm{Al}^{3+}$. All substitution schemes showed an increase in solution energy with increasing $\mathrm{M}^{4+}$ concentration, with two exceptions. In the case of $\mathrm{Ce}^{4+}$ substitution with $\mathrm{Fe}^{3+}$ charge balancing on the Ti(1)Ti(3) site, the solution energy decreased with increased $\mathrm{Ce}^{4+}$ concentration, however, we observe a large increase in solution energy in the compositional interval between $18-21 \% \mathrm{Ce}^{4+}$ incorporation. Whereas, in the case of $\mathrm{U}^{4+}$ substitution with $\mathrm{Fe}^{3+}$ charge balancing on $\operatorname{Ti}(2) \operatorname{Ti}(3)$ sites, the solution energies for each compositional interval are much lower than for counterpart $\mathrm{M}^{4+}$ substitutions.

\section{Discussion}

The negative solution energies presented in Fig. 3 suggest that zirconolite-2M may fully accommodate $\mathrm{Ce}^{4+}, \mathrm{U}^{4+}, \mathrm{Th}^{4+}$ and $\mathrm{Pu}^{4+}$ on the $\mathrm{Zr}^{4+}$ site at low to moderate concentrations, which is in broad agreement with experimental validations for corresponding $\mathrm{CaZr}_{1-x} \mathrm{M}_{x} \mathrm{Ti}_{2} \mathrm{O}_{7}$ solid solutions $(\mathrm{M}=\mathrm{Ce}, \mathrm{U}, \mathrm{Th}, \mathrm{Pu})$. Furthermore, as the concentration of substitution is increased, the mixing of $\mathrm{Ce}^{4+}, \mathrm{U}^{4+}$ and $\mathrm{Pu}^{4+}$ is increasingly favoured, but only up to a value of $15 \%$ in the case of $\mathrm{U}^{4+}$, where we observe a discontinuity in solution energy. The observed discontinuity in solution energy for $\mathrm{U}^{4+}$ is consistent with the apparent solid solution limit of $\mathrm{U}$ in the zirconolite-2M structure as reported by Vance et al. ${ }^{13}$ Transformation to the zirconolite-4M polytype structure was reported in excess of approximately $15 \% \mathrm{U}^{4+}$ substitution in the $\mathrm{Zr}^{4+}$ site of the zirconolite-2M structure. ${ }^{13}$ The $4 \mathrm{M}$ polytype also crystallises in the space group $C 2 / c$ and is commonly described as an intergrowth of zirconolite-2M and pyrochlore-type layers, parallel to the [001] axis, resulting in a doubling of the unit cell. ${ }^{52}$ The zirconolite-4M phase remains the dominant structure in the $\mathrm{CaZr}_{1-x} \mathrm{U}_{x} \mathrm{Ti}_{2} \mathrm{O}_{7}$ system up to a value of approximately $40 \%$ substitution, after which the cubic pyrochlore $\mathrm{CaUTi}_{2} \mathrm{O}_{7}$-type structure is preferred. Similar solid solution limits for $\mathrm{Ce}$ in the corresponding $\mathrm{CaZr}_{1-x} \mathrm{Ce}_{x} \mathrm{Ti}_{2} \mathrm{O}_{7}$ system were reported by Blackburn et al..$^{53}$ and Begg et al. ${ }^{54}$ with the Ce inventory preferentially accommodated in the zirconolite-4M structure above $20 \%$ incorporation. However, it must be recognised that the tendency of $\mathrm{Ce}^{4+}$ to undergo reduction to $\mathrm{Ce}^{3+}$, when processing under inert or reducing conditions, does not permit formation of zirconolite-4M in the same solid solution, rather a Ce-rich $\mathrm{CaTiO}_{3}$ phase is preferentially formed. ${ }^{53}$ Nevertheless, targeting equimolar $\mathrm{Ce}^{3+}$ substitution between $\mathrm{Ca}^{2+}$ and $\mathrm{Zr}^{4+}$ sites, i.e. $\mathrm{Ca}_{1-x} \mathrm{Zr}_{1-x} \mathrm{Ce}_{2 x^{-}}$ $\mathrm{Ti}_{2} \mathrm{O}_{7}$ was observed to yield a transformation to zirconolite4M. ${ }^{55}$ Begg et al. fabricated the $\mathrm{CaZr}_{1-x} \mathrm{Pu}_{x} \mathrm{Ti}_{2} \mathrm{O}_{7}$ solid solution confirming that $\mathrm{Pu}^{4+}$ was preferentially accommodated in the $4 \mathrm{M}$ structure at around $15 \%$ incorporation, consistent with data for $\mathrm{Ce}^{4+}$ and $\mathrm{U}^{4+} \cdot{ }^{56}$ Consequently, simulation studies of substituent reduction and polytype transitions of zirconolite are necessary.

It follows that a similar trend would be expected for $\mathrm{Pu}$ in the data presented in Fig. 3, however, a continuous trend of negative solution energy was observed. It should be noted that a number of configurations did fail to optimise in our simulations, suggesting that certain defect arrangements are highly unfavourable. This may correspond to experimental observations, in which the $2 \mathrm{M}$ structure becomes less favourable towards high substitution concentrations, possibly due to substituent proximity within a lattice. Our observation that $\mathrm{Ce}^{4+}$ and $\mathrm{Pu}^{4+}$ substitute favourably for $\mathrm{Zr}^{4+}$ in zirconolite is further supported by the observations of Gilbert et al. ${ }^{24}$ These data indicate that, whilst Ce remains a safe and practical analogue for Pu in wasteform development trials, it cannot fully replicate the substitution behaviour of $\mathrm{Pu}$ in zirconolite. Despite a similar trend to $\mathrm{Pu}^{4+}$ and $\mathrm{U}^{4+}$ at low concentrations, a clear variation in the solution energy, as a function of substitution, was observed. Nevertheless, the limitations of Ce-Pu surrogacy have been previously discussed in the context of Pu immobilisation in ceramic materials. ${ }^{57,58}$

In contrast, the substitution of $\mathrm{Th}^{4+}$ for $\mathrm{Zr}^{4+}$ produces a continuous positive upward trend in solution energy, which becomes positive above $9 \%$ Th substitution, suggesting that $\mathrm{Th}^{4+}$ may have a narrow solid solution range in the zirconolite$2 \mathrm{M}$ structure. These data are consistent with recent observations by Blackburn et al. ${ }^{59}$ in which it was confirmed that the solubility of $\mathrm{Th}^{4+}$ in the $\mathrm{CaZr}_{1-x} \mathrm{Th}_{x} \mathrm{Ti}_{2} \mathrm{O}_{7}$ solid solution was limited to $10 \%$ substitution for $\mathrm{Zr}^{4+}$, with $\mathrm{Th}^{4+}$ preferentially accommodated in a pyrochlore-structured phase between 0.10 $\leq x \leq 0.50$. The single phase pyrochlore compound $\mathrm{CaZr}_{0.40^{-}}$ $\mathrm{Th}_{0.60} \mathrm{Ti}_{2} \mathrm{O}_{7}$ was produced when targeting $x=0.60$. Interestingly, a phase transition to the zirconolite- $4 \mathrm{M}$ structure, as reported in analogue $\mathrm{Ce}$ and $\mathrm{U}$ solid solutions, was not observed.

The data presented in Fig. 4 and 5 demonstrate that the substitution of $\mathrm{Ce}^{4+}, \mathrm{U}^{4+}, \mathrm{Th}^{4+}$ and $\mathrm{Pu}^{4+}$ in the $\mathrm{Ca}^{2+}$ site, with charge balance provided by $\mathrm{Al}^{3+}$ and $\mathrm{Fe}^{3+}$ is favoured at $\mathrm{M}^{4+}$ concentrations around $3 \%$. Yet, these solid solutions become rapidly unfavourable, tending towards positive solution energy 
with the exception of the substitution scheme in which charge compensators were accommodated in the $\mathrm{Ti}(2)$ site. This substitution scheme follows a downward trend in solution energy, suggesting that surrogate species may be accommodated in the $\mathrm{Ca}^{2+}$ site up to a $21 \%$ substitution, with $\mathrm{Al}^{3+}$ and $\mathrm{Fe}^{3+}$ preferentially accommodated in the $\mathrm{Ti}(2)$ site, consistent with some experimental observations. Loiseau et al. ${ }^{\mathbf{6 0}}$ fabricated the $\mathrm{Ca}_{1-x} \mathrm{Nd}_{x} \mathrm{ZrTi}_{2-x} \mathrm{Al}_{x} \mathrm{O}_{7}$ solid solution, confirming that zirconolite-2M was produced as a single phase in the compositional range $x \leq 0.60$, with $\mathrm{Nd}^{3+}$ deployed as a trivalent actinide surrogate, and further substitution resulted in the formation of the orthorhombic 30 polytype. Rietveld refinement of a zirconolite-2M structural model, in which $\mathrm{Al}^{3+}$ was constrained in the $\mathrm{Ti}(2)$ site, was refined against powder X-ray diffraction data for $\mathrm{Ca}_{0.7} \mathrm{Nd}_{0.3} \mathrm{ZrTi}_{1.7} \mathrm{Al}_{0.3} \mathrm{O}_{7}$, confirmed that $\mathrm{Al}^{3+}$ preferentially occupied this site relative to $\mathrm{Ti}(1)$ and $\mathrm{Ti}(3)$. Similarly, $\mathrm{Fe}^{3+}$ was demonstrated by Whittle et al. ${ }^{37}$ to substitute for $\mathrm{Ti}(2)$ in the $\mathrm{CaZrTi}_{2-2 x} \mathrm{Nb}_{x} \mathrm{Fe}_{x} \mathrm{O}_{7}$ solid solution, however, it must be recognised that no surrogate as targeted to replace $\mathrm{Ca}^{2+}$. Conversely, Fe K-edge XANES has failed to resolve any preferential occupation of $\mathrm{Fe}^{3+}$ between $\mathrm{Ti}(1) / \mathrm{Ti}(3)$ and $\mathrm{Ti}(2)$ sites in the $\mathrm{Ca}_{1-x} \mathrm{Ho}_{x} \mathrm{ZrTi}_{2-x} \mathrm{Fe}_{x} \mathrm{O}_{7}{ }^{61}$ Similarly, Forder et al. ${ }^{62}$ resolved $\mathrm{Fe}^{3+}$ coordination in single phase zirconolite-2M (targeting $\left.\mathrm{Ca}_{1-x} \mathrm{Ce}_{x} \mathrm{ZrTi}_{2-2 x} \mathrm{Fe}_{2 x} \mathrm{O}_{7}\right)$ using ${ }^{57} \mathrm{Fe}$ Mössbauer spectroscopy, confirming that whilst $\mathrm{Fe}^{3+}$ occupied both $5^{-}$and 6fold coordination $\mathrm{Ti}^{4+}$ sites, occupation of the $\mathrm{Ti}(2)$ site was preferred at low $\mathrm{Fe}^{3+}$ concentration. Previous simulation studies did not identify a significant preference of $\mathrm{Fe}^{3+}$ in any particular $\mathrm{Ti}^{4+}$ site of zirconolite-2M. ${ }^{24} \mathrm{Cr}^{3+}$ coordination was probed by Blackburn et al. in the $\mathrm{Ca}_{1-x} \mathrm{Ce}_{x} \mathrm{ZrTi}_{2-2 x} \mathrm{Cr}_{2 x} \mathrm{O}_{7}$ system, with deconvolution of the pre-edge Cr K-edge XANES region consistent with $\mathrm{Cr}^{3+}$ arranged in 6-fold coordination, inferring occupation in the octahedral $\mathrm{Ti}(1)$ and $\mathrm{Ti}(3)$ sites, as expected from consideration of crystal field stabilisation energy. ${ }^{63}$

The variation in dominant charge compensation mechanism and preferential site occupancy of charge compensation species in zirconolite-2M may be attributed to a several factors, not limited to: the choice of $\mathrm{Pu}$ surrogate deployed, the valence state, electronic structure and ionic radius of the charge compensation cation, and the partial oxygen pressure imposed during the fabrication route, which has been systematically demonstrated to influence both surrogate oxidation state and partitioning in the zirconolite-2M structure. This work also provided some evidence that, in line with experimental observations, $\mathrm{Pu}^{4+}$ may be favourably accommodated on the $\mathrm{Ca}^{2+}$ site in the zirconolite structure, whereas substitution of $\mathrm{Ce}^{4+}$ may be unfavourable in some instances. However, it is important to note that the underlying mechanism constraining the site occupancy of Ce within zirconolite-2M is controlled by the prevailing redox conditions imposed during synthesis, and is not entirely governed by the chosen solid solution regime. Whereas $\mathrm{Pu}^{4+}$ is readily incorporated in the zirconolite-2M phase under oxidising conditions, $\mathrm{Ce}^{4+}$ has a tendency to partially reduce to $\mathrm{Ce}^{3+}$ regardless of sintering environment. For example, synthesis of the $\mathrm{CaZr}_{1-x} \mathrm{Ce}_{x} \mathrm{Ti}_{2} \mathrm{O}_{7}$ and $\mathrm{Ca}_{1-x} \mathrm{Ce}_{x^{-}}$ $\mathrm{ZrTi}_{2-2 x} \mathrm{Cr}_{2 x} \mathrm{O}_{7}$ solid solutions in air consistently resulted in partial reduction of the $\mathrm{Ce}^{4+}$ inventory to $\mathrm{Ce}^{3+}$. It is this underlying auto-reduction tendency, that does not present itself with $\mathrm{Pu}$ under such conditions, that is the limiting factor in $\mathrm{Ce}-$ $\mathrm{Pu}$ surrogacy. Near single phase zirconolite- $2 \mathrm{M}$ materials with nominal composition $\mathrm{Ca}_{0.8} \mathrm{Pu}_{0.2} \mathrm{HfTi}_{1.6} \mathrm{Al}_{0.4} \mathrm{O}_{7}$ and $\mathrm{Ca}_{0.8} \mathrm{Pu}_{0.2^{-}}$ $\mathrm{ZrTi}_{1.8} \mathrm{Al}_{0.2} \mathrm{O}_{7}$ have been previously reported by both conventional sintering and hot pressing techniques, targeting $\mathrm{Pu}^{4+}$ and $\mathrm{Pu}^{3+}$ respectively. ${ }^{\mathbf{2 0 , 6 4}}$ Analysis of the compositionally analogous $\mathrm{Ca}_{1-x} \mathrm{Ce}_{x} \mathrm{ZrTi}_{2-2 x} \mathrm{Al}_{2 x} \mathrm{O}_{7}$ solid solution, at $x=0.10$, has been observed to produce a minor perovskite phase, attributed to partial $\mathrm{Ce}^{3+}$ speciation-2M. ${ }^{65}$ The differences between simulated $\mathrm{Ce}^{4+}$ and $\mathrm{Pu}^{4+}$ substitution behaviour suggests that clustering and localised substituent-substituent interactions, which would be present in the current work yet excluded from previous data, ${ }^{24}$ may be key for stabilising the substituents. The combined presence of numerous defects may relieve the localised stress they create, as opposed to lone, or few, defects. ${ }^{28}$ This may also explain the data presented by $\mathrm{Ji}$ et al. $^{61}$ where the incorporation of $\mathrm{Ln}^{3+}$ species in the $\mathrm{Ca}^{2+}$ site would lead to a weaker binding energy with $\mathrm{Fe}^{3+}$ defects distributed across the $\mathrm{Ti}^{4+}$ sites, and thus preferential occupation of $\mathrm{Fe}^{3+}$ within any specific $\mathrm{Ti}^{4+}$ site was not reported. It remains clear that in the present study, and as has been confirmed in a selection of laboratory investigations, that low valence charge balancing cations preferentially occupy the trigonal biprymidal $\mathrm{TiO}_{5}$ site. It follows that the partially occupied nature of this site $(50 \%$ occupied), relative to $\mathrm{Ti}(1)$ and $\mathrm{Ti}(3)$, permits the accommodation of cations of varied size.

From examination of the collective substituent behaviour we establish that at low concentrations (e.g. 3\%) a selection of charge compensated substitution schemes are viable within the zirconolite-2M phase, and it has been experimentally determined that environmental conditions, chemical activity and ion mobility may dictate the solid solution mechanisms that occur. As the nominal concentration of substitution is increased, it is to be expected that clustering of defects will occur in either the $\mathrm{Zr}^{4+}$ site or $\mathrm{Ca}^{2+}$ site, facilitated by charge compensation on the Ti(2) site. The investigation presented herein shows that substitution schemes involving the $\mathrm{Ca}^{2+}$ site reach lower solution energies when charge balancing with $\mathrm{Al}^{3+}$ on the $\mathrm{Ti}(2)$ site, this requires further computational work to elucidate, an interpretation is that $\mathrm{Al}^{3+}$ being smaller than $\mathrm{Fe}^{3+}$ can be accommodated more easily. Nevertheless, these data support the deployment of zirconolite- $2 \mathrm{M}$ as a potential single host phase for the immobilisation of $\mathrm{Pu}$ oxides, and are in general agreement with a selection of recent publications concerning the solid solution behaviour of $\mathrm{Ce}, \mathrm{U}$, Th and $\mathrm{Pu}$.

\section{Conclusions}

We have demonstrated trends in the energetics of zirconolite$2 \mathrm{M}$ solid solutions with $\mathrm{Ce}^{4+}, \mathrm{Pu}^{4+}, \mathrm{Th}^{4+}$, and $\mathrm{U}^{4+}$ cations that are in general agreement with published experimental data concerning the deployment of zirconolite-2M as a host for actinides. Consequently, we have shown that atomistic simulations can effectively guide the formulation development of these materials, and inform experimental validation. For example, using the high throughput methodology developed 
and reported here, it is possible to rapidly screen many solid solution schemes in silico and evaluate their relative stability, to guide more resource intensive $a b$ initio simulations and laboratory investigation for validation. Indeed, this method should have much wider utility in the exploration in the optimisation of functional materials such as high entropy alloys, capacitor ceramics, and perovskite catalysts. Our investigations have also shown that Ce is not a direct analogue for the actinide cations such as $\mathrm{Pu}$, as has been validated in a number of wasteform development trials.

\section{Author contributions}

S. D. - data curation, investigation, formal analysis, methodology, software, visualization, writing - original draft, writing review \& editing. C. M. H. - conceptualization, formal analysis, investigation, methodology, software, writing - review \& editing. L. R. B. - investigation, validation, writing - review \& editing. C. L. F. - project administration, resources, supervision, writing - review \& editing. N. C. H. - conceptualization, funding acquisition, project administration, resources, supervision, writing - review \& editing.

\section{Conflicts of interest}

There are no conflicts to declare.

\section{Acknowledgements}

We are grateful for financial support from the Nuclear Decommissioning Authority and EPSRC under grant reference EP/ S01019X/1 and EP/R511754/1. This research utilised the HADES/MIDAS facility at the University of Sheffield established with financial support from EPSRC and BEIS, under grant EP/ T011424/1. ${ }^{66}$ The computational work was made possible by the resources provided by Research-IT at the University of Sheffield. We would also like to extend our gratitude to Ondřej Krejčí for invaluable input on the presentation of this work.

\section{Notes and references}

1 N. C. Hyatt, npj Mater. Degrad., 2020, 4, 28.

2 W. J. Weber, R. C. Ewing, C. A. Angell, G. W. Arnold, A. N. Cormack, J. M. Delaye, D. L. Griscom, L. W. Hobbs, A. Navrotsky, D. L. Price, A. M. Stoneham and M. C. Weinberg, J. Mater. Res., 1997, 12, 1948-1978.

3 W. J. Weber, R. C. Ewing, C. R. A. Catlow, T. D. de la Rubia, L. W. Hobbs, C. Kinoshita, H. Matzke, A. T. Motta, M. Nastasi, E. K. H. Salje, E. R. Vance and S. J. Zinkle, J. Mater. Res., 1998, 13, 1434-1484.

4 R. C. Ewing, Earth Planet. Sci. Lett., 2005, 229, 165-181.

5 R. C. Ewing, Prog. Nucl. Energy, 2007, 49, 635-643.

6 N. C. Hyatt and M. I. Ojovan, Materials, 2019, 12, 3611.

7 R. C. Ewing, C. R. Geosci., 2011, 343, 219-229.

8 A. E. Ringwood, S. E. Kesson, N. G. Ware, W. Hibberson and

A. Major, Nature, 1979, 278, 219-223.
9 W. Lutze and R. C. Ewing, Radioactive waste forms for the future, North-Holland, 1988.

10 K. P. Hart, E. R. Vance, M. W. A. Stewart, J. Weir, M. L. Carter, M. Hambley, A. Brownscombe, R. A. Day, S. Leung, C. J. Ball, B. Ebbinghaus, L. Gray and T. Kan, MRS Proceedings, 1997, 506, 161.

11 K. Zhang, B. Luo and H. Zhang, Mater. Res. Express, 2019, 6, 115526.

12 R. F. Haaker and R. C. Ewing, Naturally occurring crystalline phases: analogues for radioactive waste forms, Richland, WA (United States), 1981.

13 E. R. Vance, G. R. Lumpkin, M. L. Carter, D. J. Cassidy, C. J. Ball, R. A. Day and B. D. Begg, J. Am. Ceram. Soc., 2002, 85, 1853-1859.

14 X. Deschanels, V. Picot, B. Glorieux, F. Jorion, S. Peuget, D. Roudil, C. Jégou, V. Broudic, J. N. Cachia, T. Advocat, C. Den Auwer, C. Fillet, J. P. Coutures, C. Hennig and A. Scheinost, J. Nucl. Mater., 2006, 352, 233-240.

15 L. R. Blackburn, D. J. Bailey, S.-K. Sun, L. J. Gardner, M. C. Stennett, C. L. Corkhill and N. C. Hyatt, Adv. Appl. Ceram., 2021, 120, 69-83.

16 B. M. Gatehouse, I. E. Grey, R. J. Hill and H. J. Rossell, Acta Crystallogr., Sect. B: Struct. Crystallogr. Cryst. Chem., 1981, 37, 306-312.

17 H. J. Rossell, Nature, 1980, 283, 282-283.

18 M. C. Stennett, C. L. Corkhill, L. A. Marshall and N. C. Hyatt, J. Nucl. Mater., 2013, 432, 182-188.

19 B. D. Begg, E. R. Vance and G. R. Lumpkin, MRS Proceedings, 1997, 506, 79.

20 B. D. Begg and E. R. Vance, MRS Proceedings, 1996, 465, 333.

21 C. Dickson and F. Glasser, Cem. Concr. Res., 2000, 30, 16191623.

22 W. A. Lambertson, M. H. Mueller and F. H. Gunzel, J. Am. Ceram. Soc., 1953, 36, 397-399.

23 P. W. Tasker, Le Journal de Physique Colloques, 1980, 41, C6488-C6-491.

24 M. Gilbert and J. H. Harding, Phys. Chem. Chem. Phys., 2011, 13, 13021.

25 L. Veiller, J.-P. Crocombette and D. Ghaleb, J. Nucl. Mater., 2002, 306, 61-72.

26 H. R. Foxhall, K. P. Travis, L. W. Hobbs, S. C. Rich and S. L. Owens, Philos. Mag., 2013, 93, 328-355.

27 H. R. Foxhall, K. P. Travis and S. L. Owens, J. Nucl. Mater., 2014, 444, 220-228.

28 J. Tanti and N. Kaltsoyannis, J. Nucl. Mater., 2021, 543, 152525.

29 J. A. Fortner, A. J. Kropf, A. J. Bakel, M. C. Hash, S. B. Aase, E. C. Buck and D. B. Chamberlain, MRS Proceedings, 1999, 608, 401.

30 J. A. Fortner, A. J. Kropf, R. J. Finch, A. J. Bakel, M. C. Hash and D. B. Chamberlain, J. Nucl. Mater., 2002, 304, 56-62.

31 C. Nästren, R. Jardin, J. Somers, M. Walter and B. Brendebach, J. Solid State Chem., 2009, 182, 1-7.

32 D. J. Gregg, Y. Zhang, S. C. Middleburgh, S. D. Conradson, G. Triani, G. R. Lumpkin and E. R. Vance, J. Nucl. Mater., 2013, 443, 444-451. 
33 S. Finkeldei, M. C. Stennett, P. M. Kowalski, Y. Ji, E. de Visser-Týnová, N. C. Hyatt, D. Bosbach and F. Brandt, J. Mater. Chem. A, 2020, 8, 2387-2403.

34 R. L. Miller and G. A. Reimann, Thermodynamics of gas-metalslag equilibria for applications in in situ and ex situ vitrification melts, 1993.

35 P. Loiseau, D. Caurant, N. Baffier, L. Mazerolles and C. Fillet, J. Nucl. Mater., 2004, 335, 14-32.

36 G. R. Lumpkin, K. R. Whittle, C. J. Howard, Z. Zhang, F. J. Berry, G. Oates, C. T. Williams and A. N. Zaitsev, MRS Proceedings, 2006, 932, 53.1.

37 K. R. Whittle, N. C. Hyatt, K. L. Smith, I. Margiolaki, F. J. Berry, K. S. Knight and G. R. Lumpkin, Am. Mineral., 2012, 97, 291-298.

38 F. J. Berry, G. R. Lumpkin, G. Oates and K. R. Whittle, Hyperfine Interact., 2006, 166, 363-366.

39 M. R. Gilbert, C. Selfslag, M. Walter, M. C. Stennett, J. Somers, N. C. Hyatt and F. R. Livens, IOP Conf. Ser.: Mater. Sci. Eng., 2010, 9, 012007.

40 K. Momma and F. Izumi, J. Appl. Crystallogr., 2011, 44, 12721276.

41 J. D. Gale and A. L. Rohl, Mol. Simul., 2003, 29, 291-341.

42 M. Born and K. Huang, Dynamical Theory of Crystal Lattices, Clarendon Press, 1954.

43 B. G. Dick and A. W. Overhauser, Phys. Rev., 1958, 112, 90103.

44 C. G. Broyden, Mathematics of Computation, 1970, 24, 365.

45 R. Fletcher, Comput. J., 1970, 13, 317-322.

46 D. Goldfarb, Mathematics of Computation, 1970, 24, 23.

47 D. F. Shanno, Mathematics of Computation, 1970, 24, 647.

48 T. S. Bush, J. D. Gale, C. R. A. Catlow and P. D. Battle, J. Mater. Chem., 1994, 4, 831.

49 S. M. Woodley, P. D. Battle, J. D. Gale and C. R. A. Catlow, Phys. Chem. Chem. Phys., 1999, 1, 2535-2542.

50 M. Nadeem, M. J. Akhtar, R. Shaheen, M. N. Haque and a Y. Khan, J. Mater. Sci. Technol., 2001, 17, 638-642.
51 C. R. A. Catlow, in Solid State Chemistry Techniques, Clarendon Press, 1987, ch. 7.

52 A. A. Coelho, R. W. Cheary and K. L. Smith, J. Solid State Chem., 1997, 129, 346-359.

53 L. R. Blackburn, S. Sun, L. J. Gardner, E. R. Maddrell, M. C. Stennett and N. C. Hyatt, J. Nucl. Mater., 2020, 535, 152137.

54 B. D. Begg, E. R. Vance, R. Day, M. Hambley and S. D. Conradson, MRS Proceedings, 1996, 465, 325.

55 C. Meng, X. Ding, W. Li, J. Zhao and H. Yang, J. Mater. Sci., 2016, 51, 5207-5215.

56 B. D. Begg, R. A. Day and A. Brownscombe, MRS Proceedings, 2000, 663, 259.

57 P. A. Bingham, R. J. Hand, M. C. Stennett, N. C. Hyatt and M. T. Harrison, MRS Proceedings, 2008, 1107, 421.

58 M. V. Zamoryanskaya and B. E. Burakov, MRS Proceedings, 2000, 663, 301.

59 L. R. Blackburn, S. Sun, L. J. Gardner, E. R. Maddrell, M. C. Stennett, C. L. Corkhill and N. C. Hyatt, J. Am. Ceram. Soc., 2020, 2.

60 P. Loiseau, D. Caurant, N. Baffier and C. Fillet, MRS Proceedings, 2002, 757, II6.3.

61 S. Ji, M. Su, C. Liao, S. Ma, Z. Wang, K. Shih, C. Chang, J. Lee, T. Chan and Y. Li, J. Am. Ceram. Soc., 2020, 103, 1463-1475.

62 S. D. Forder, P. A. Bingham, O. J. McGann, M. C. Stennett and N. C. Hyatt, Hyperfine Interact., 2013, 217, 83-90.

63 L. R. Blackburn, S.-K. Sun, S. M. Lawson, L. J. Gardner, H. Ding, C. L. Corkhill, E. R. Maddrell, M. C. Stennett and N. C. Hyatt, J. Eur. Ceram. Soc., 2020, 40, 5909-5919.

64 E. R. Vance, C. J. Ball, R. A. Day, K. L. Smith, M. G. Blackford, B. D. Begg and P. J. Angel, J. Alloys Compd., 1994, 213-214, 406-409.

65 L. R. Blackburn, S. K. Sun, L. J. Gardner, E. R. Maddrell, M. C. Stennett and N. C. Hyatt, MRS Adv., 2020, 5, 93-101.

66 N. C. Hyatt, C. L. Corkhill, M. C. Stennett, R. J. Hand, L. J. Gardner and C. L. Thorpe, IOP Conf. Ser.: Mater. Sci. Eng., 2020, 818, 012022. 